\title{
Ideologiese normverplasings en die Afrikaanse handwoordeboek van die negentigerjare
}

\author{
Adelia Carstens \\ Departement Afrikaans \\ Universiteit van Pretoria \\ PRETORIA
}

\begin{abstract}
Ideological norm replacement and the Afrikaans desk dictionary of the nineties

In South Africa the past decade has been marked by extensive sociopolitical changes and by concomitant linguistic changes. These changes may be regarded as instances of norm replacement - a process during the course of which a norm or a set of norms is gradually replaced by another norm or set of norms. It is maintained that the standard synchronic dictionaries of a language not only have the obligation to reflect lexicalised norm replacements, but also to make projections with regard to future use. Two standard synchronic desk dictionaries of Afrikaans, namely the eighth edition of Verklarende Afrikaanse Woordeboek (1992) and the third edition of Verklarende Handwoordeboek van die Afrikaanse Taal (1994) are explored with special regard to their reflection of norm replacements within the domains of race and political ideology. It is shown that the compilers of these dictionaries consciously and sincerely aimed at removing all racial bias but that they failed to record the diversity of meaning within the political lexicon and the semantic shifts which have occurred within that lexicon during the past decade.
\end{abstract}

\section{Inleiding}

Uit die geskiedenis blyk dit dat Afrikaanse handwoordeboeke ongeveer elke dekade hersien word - om enersyds verskuiwings van diverse aard binne die standaardtaalleksikon te weerspieël en om andersyds naas die Afrikaanse Woordelys en Spelreëls as gesaghebbende normatiewe handleiding vir gebruikers te dien.

Dit wil voorkom asof daar met meer as die normale dosis afwagting na die woordeboekgenerasie van negentig uitgesien is - deur sowel konsensieuse taalgebruikers as deur taalkundiges. Een van die redes is dat daar gedurende die deka- 
de van tagtig tot negentig soveel ingrypende sosio-politieke en normatief-taalkundige verskuiwings in Afrikaans plaasgevind het.

In hierdie bydrae word twee Afrikaanse handwoordeboeke wat sedert die begin van die negentigerjare verskyn het, te wete Verklarende Afrikaanse Woordeboek $\left(V A W^{\beta}\right)$ en Verklarende Handwoordeboek van die Afrikaanse Taal ${ }^{3}\left(H A T^{3}\right)$, met betrekking tot hulle sosiolinguistiese relevansie gemeet aan die mate waarin hulle die normverplasings van die afgelope dekade weerspieël.

\section{Die begrip normverplasing}

Volgens Bartsch (1982:61) is een van die primêre funksies van norme om sosiaalrelevante aktiwiteite en handelinge in 'n gemeenskap - ook in 'n taalgemeenskap - te definieer (vergelyk ook Carstens, 1994:4-6). Norme is in beginsel konserwatief en indiwidue raak maklik verkleef daaraan, hoofsaaklik omdat norme riglyne voorsien vir gepaste sosiale optrede. Volgens Bartsch (1981:89) kan norme egter wel onder bepaalde omstandighede verander:

* Norme kan kreatief geskend word ter handhawing van die hoogste kommunikasienorm, naamlik onderlinge verstaanbaarheid. Taalkundige norme op fonologiese, morfologiese, semantiese, sintaktiese, pragmatiese en ortografiese vlak kan dus verskuiwings ondergaan ter wille van die handhawing van die hoogste kommunikasienorm.

* Norme kan wysigings ondergaan indien nuwe wetenskaplike insigte en tegnieke ontwikkel word. Ontwikkelinge in die taalteorie en die metaleksikografie kan veranderinge in woordeboeke dikteer, onder andere ter wille van groter sistematiek en makliker/vinniger inligtingontsluiting.

* Indien daar 'n nuwe sosiale orde of nuwe sosiale betrekkinge in 'n gemeenskap tot stand kom, mag normwysiging noodsaaklik wees. Die verskansing van groepregte deur streng taalnormering lei dikwels tot eksklusiwiteit en soms ook tot etnosentrisme - 'n verskynsel wat in die sosiokulturele geskiedenis van Afrikaans duidelik merkbaar is. Wanneer hierdie verknogtheid aan bepaalde norme egter die voortbestaan van ' $n$ taal in gevaar stel of wanneer 'n nuwe politieke bestel verandering afdwing, moet dit noodwendig tot normveranderings lei.

Hoewel Bartsch se beskouings in verband met norme in hoofsaak deur die outeur van hierdie artikel onderskryf word, word Van Rensburg (1994:172) se term normverplasing verkies bo Bartsch $(1981 ; 1982)$ se term normverandering. Daar word met Van Rensburg saamgestem dat norme self nie 'verander' nie, maar wel die persepsies van sprekers oor die geldigheid van norme. Verder word 
aanvaar dat 'n stel ou norme nie eensklaps deur 'n stel nuwe norme vervang word nie. Die ou norme bly gewoonlik vir 'n tyd lank naas die nuwes voortbestaan en word eers met verloop van tyd volkome verdring deur die nuwes.

Aangesien woordeboeke die taalwerklikheid getrou moet weerspieël, moet hulle ook die normverplasings weerspieël wat in 'n gemeenskap plaasvind. Een van die probleme wat sentraal staan in die leksikografiese reflektering van normverplasings is die feit dat ' $n$ mens met prosesse en nie met gebeurtenisse te doen het nie. Vasstelling van die norme op 'n gegewe tydstip is dus dikwels problematies, behalwe miskien in die geval van preskriptiewe normering - soos spellingbereëling - wat gekoppel kan word aan 'n vaste datum en 'n gesaghebbende publikasie. Die leksikograaf is gewoonlik aangewese op sy/haar interpretasie van taalgebruiksdata wat in terme van frekwensie en spreiding as verteenwoordigend beskou kan word.

Daar is veral drie tipes normverplasings wat gedurende die afgelope dekade prominent geword het en wat belangrike implikasies vir die Afrikaanse leksikografie het, naamlik metaleksikografiese, preskriptiewe en ideologiese normverplasings. Vervolgens word 'n kort oorsig gegee van eersgenoemde twee tipes en daarna word ideologiese normverplasings in meer besonderhede bespreek.

\section{Metaleksikografiese normverplasings}

Volgens Gouws (1989:24) staan die tagtigerjare bekend as die "Goue Eeu van die Leksikografie". Gedurende hierdie dekade het die leksikografie op sowel nasionale as internasionale gebied 'n ongekende oplewing ondervind. Die kloof tussen taalwetenskap, metaleksikografie en taalgebruik is ook in 'n hoe mate oorbrug. Daar sou dus met reg verwag kon word dat die woordeboekgenerasie van negentig die belangrikste ontwikkelinge op die gebied van die teoretiese leksikografie moet reflekteer - veral in die mate wat hierdie ontwikkelinge sou kon bydra tot die aanbied van beter gebruiksleiding in woordeboeke.

\section{Preskriptiewe normverplasings}

Een van die take van die standaard sinchroniese woordeboeke van ' $n$ taal is om die gebruiklikste leksikale items van daardie taal met hulle erkende ortografiese vorm(e) weer te gee volgens die riglyne en reëls van die hoogste normatiewe taalgesag. In die geval van Afrikaans is hierdie gesag tans nog gesetel in die Taalkommisie van die Suid-Afrikaanse Akademie vir Wetenskap en Kuns, met die $A W S$ as mondstuk. Een van die take van die woordeboekgenerasie van negentig sou wees om wysigings in die agste uitgawe van die Afrikaanse Woordelys en Spelreëls, wat in 1991verskyn het, sistematies te weerspieell om sodoende 
antwoorde op 'n verskeidenheid leksikale en ortografiese soekvrae aan die gebruiker te bied.

Preskriptiewe normering het egter nie uitsluitlik op leksikale en ortografiese bereèling betrekking nie; dit het ook te doen met leksikografiese sensorering. Lemmas wat ongeëtiketteerd in handwoordeboeke opgeneem word, kry outomaties die stempel van 'standaardtaalwoorde' en dié wat wel op een of ander wyse geëtiketteer word, word gemerk as 'kontekstueel ingeperk'. In Afrikaanse handwoordeboeke is kunsmatige sensuur tot en met die vorige woordeboekgenerasie volgehou vir sover dit Engelse beïnvloeding betref. Sedert die tagtigerjare het daar egter vanuit taalkundekringe stemme begin opgaan vir die sanksionering van gebruiksrealiteite, veral met betrekking tot Anglisismes (vergelyk onder andere Combrink 1984; Gouws 1993). Hierdie sensuurverslapping is onder meer gereflekteer in normatiewe woordeboeke soos Sakboek van regte Afrikaans en Die korrekte woord (Van der Merwe \& Ponelis, 1991). Negentigerwoordeboeke het eintlik geen ander keuse as om erkenning te gee aan die verskuiwing van hierdie interne norme nie en om sowel hulle opnamebeleid as sensorering van lemmas deur middel van leksikografiese kommentaar te verslap.

\section{Ideologiese normverplasings}

\subsection{Inleiding}

Gedurende geen ander era in die geskiedenis van Afrikaans het daar soveel verskuiwings plaasgevind in die sosio-politieke en ideologiese persepsies van sprekers as juis gedurende die tagtiger- en vroeë negentigerjare nie. In die breë gemeenskap het daar 'n toenemende gesindheid van verdraagsaamheid begin posvat - 'n gesindheid van 'akkommoderend' te wees teenoor sprekers met ander ideologiese inklinasies en normsisteme as die eie.

Van Rensburg (1992:183) wys daarop dat sosiale normverplasings dikwels gepaard gaan met taalnormverplasings, en gedurende die afgelope dekade het hierdie tendens merkbaar geword in die taalgebruik van Afrikaanssprekendes. Doelbewuste pogings is ook deur die media aangewend om negatiewe stereotipering te vermy. Hierdie verhoogde sensitiwiteit met betrekking tot kontroversięle leksikale items het aanleiding gegee tot 'n strewe na 'politiese korrektheid'. Pseudo-sosiale eufemismes soos informele behuising (in plaas van plakkershutte) en ontwikkelende gemeenskappe (in plaas van agtergeblewe gemeenskappe) word vandag algemeen in die nuusmedia gebruik. Seksisme word die nek ingeslaan deur onder andere die gebruik van geslagsneutrale leksikale items soos segspersoon (in plaas van segsman) en mensekrag (in plaas van mannekrag) asook deur die vermyding van die manlike voornaamwoord hy waar daar nie 
spesifiek na 'n manlike referent verwys word nie. Ook benamings wat deur bepaalde rassegroepe negatief ervaar mag word, word aangepas of vervang. In plaas van Hottentotte word Koi gebruik, en in plaas van inheemse tale of inboorlingtale word outochtone tale gebruik .

Die normatiewe taalhandleidings van die postapartheidsera, waaronder ook woordeboeke ressorteer, moet hierdie uitvloeisels van 'n 'postapartheidsideologie' noodwendig weerspieêl. 'n Simplistiese oplossing sou wees dat daar gewoon met alle vorme van stereotipering en diskriminasie weggedoen moet word. Die probleemvraag is egter volgens watter riglyne? Die opstel en implementering van 'n leksikografiese beleid word veral gekompliseer deur die feit dat daar uitlopende taalteoretiese perspektiewe bestaan rondom kwetsende leksikale materiaal.

Esterhuyse (1987) handhaaf byvoorbeeld 'n sterk deterministiese benadering. Hy meen dat 'n fiktiewe werklikheidsbeeld deur Afrikaanse handwoordeboeke (in die besonder $H A T^{2}$ ) geskets word op grond van die eensydige opname van apartheidswoorde en dat dié praktyk 'n kousale invloed op taalgebruik het. Webb (1989) daarenteen, volg 'n sosiolinguistiese benadering en beskou die taak van standaardwoordeboeke derhalwe nie as ideologies-sensorerend nie. Na sy mening kan woordeboeke dus nie 'n betekenisvolle invloed op die toekomstige taalgebruik van gebruikers uitoefen nie. Die kognitiewe benadering sluit hierby aan. Kognitiwiste (vergelyk onder andere Johnson, 1987) aanvaar dat taalgebruikers (én dus ook woordeboekgebruikers) oor bepaalde prelinguistiese kognitiewe modelle beskik waarvolgens die inligting behorende tot kennisdomeine soos byvoorbeeld die politiek, ras, geslag, godsdiens, ensovoorts, gestruktureer word, en waarvolgens individue sin maak uit hulle daaglikse ervarings. Kognitiewe strukture het egter primêr 'n kulturele ervaringsbasis - hulle word slegs gedeeltelik deur taalgebruik gevorm. Dit is dus onwaarskynlik dat taaldata wat in woordeboeke opgeneem is - en waarmee die gebruiker slegs sporadies in aanraking kom - 'n kousale invloed op sowel kognitiewe strukture as op taalgebruik sal hê.

Die samestellers van 'n woordeboek hoef natuurlik nie noodwendig 'n keuse te mak tussen die sterk deterministiese en die sosiolinguistiese benaderings nie. Albei standpunte (moontlik in gewysigde vorm) sou vir die negentigerleksikograaf nut kon hê. Uit Esterhuyse se betoog sou die argument aanvaar kon word dat die apartheidsleksikon in 'n nuwe politieke bestel geen legitimiteit en bestaansreg het nie aangesien dit ontstaan het in die mond en uit die pen van 'n nielegitieme wit establishment wat weens sy politieke en ekonomiese mag één ideologiese subleksikon van Afrikaans in woordeboeke opgeneem het. Esterhuyse se standpunt sluit ook indirek aan by die leksikografiese beskouing van Zgusta (1971:210-211), naamlik dat standaard sinehroniese woordeboeke wel op die huidige woordeskat moet konsentreer, maar ook projeksies oor toekomstige 
taalgebruik moet kan maak op grond van die sistematiek van bepaalde taalgebruikstendense. Sodanige projeksies sou as 'n handige kompas kon dien om verantwoordelike leksikografie te rig. Dit sou die leksikograaf selfs daartoe kon lei om die skrapping van eensydige 'apartheidswoordeskat' ernstig te oorweeg. Webb se betoog sou weer die insig kon bring dat taalgebruikers 'n woordeboek nie holisties beskou of hanteer nie, maar atomisties, en dat die ideologiese struktuur van die opgenome leksikon nie op grond van sporadiese gebruik deur die gebruiker sistemies geïnternaliseer sal word nie. Dit impliseer dat kontroversiële lemmas nie summier geskrap moet word nie, maar dat hulle eerder opgeneem moet word met die nodige perspektiwisering deur etikette en gebruiksadvies.

Ideologie is kennelik 'n baie uitgebreide verskynsel en word onder andere gemanifesteer op die terreine van ras, geslag, politiek en godsdiens. In hierdie bydrae word slegs aan normverplasings op die gebied van rassebeskouings en partypolitiek aandag geskenk en aan die mate waarin hierdie normverplasings gereflekteer word in $V A W^{\beta}$ en $H A T^{3}$.

\subsection{Rassisme}

\subsubsection{Makrostrukturele aanpassings}

Sowel in die "Voorwoord" as die "Gids vir die gebruiker" maak die samestellers van $V A W^{8}$ geen eksplisiete melding van rassistiese of ander kwetsende leksikale items nie. In die "Voorwoord" word slegs die volgende algemene stelling gemaak: "Talle verouderde lemmas is geskrap en baie nuwes is opgeneem." Vir die gebruiker impliseer dit waarskynlik dat woorde geskrap is wat in onbruik geraak het, en wat miskien nog net in ou geskrifte of in die taalgebruik van ouer sprekers voorkom. Nadere ondersoek het egter getoon dat van die ongeveer 200 lemmas wat onder die letter $K$ alléén geskrap is, slegs ongeveer die helfte as 'temporeel verouderd' beskou kan word. Die ander 100 lemmas kwalifiseer eerder as 'ideologies verouderd' omdat hulle gedurende die apartheidsera geskep is deur die ekonomies en polities dominante rasgroep (die sogenaamde blankes) om op neerhalende of beledigende wyse na die sogenaamde swart en bruin rasgroepe te verwys, of om apartheidstrukture te sanksioneer. Onder die benoemers van eensydige rassestereotipes ressorteer die lemma Kaffer asook sowat 68 verklaarde komposita met kaffer-as eerste stam, die lemma Koelie plus vyf verklaarde komposita met Koelie- as eerste stam, asook vier verklaarde komposita met -meid as laaste stam. Hierbenewens is ook vyf verklaarde komposita met kombuis- (as pejoriserende bepalerstam) geskrap, sowel as ses verklaarde komposita met kleur- as eerste stam. Boer is waarskynlik nie geskrap nie omdat dit dikwels melioratief gebruik word. Soos uit Tabel 1 blyk, is die definiens (vgl. Gouws, 1989:39) in die agste uitgawe van $V A W$ wel gewysig deur Suid-Afrikaner 
te vervang met Afrikaner en die lande van herkoms uit te brei na Frankryk en Duitsland. Ongelukkig word die pejoratiewe betekenis- en gebruikswaardes van Boer steeds nie verreken nie.

\section{Tabel 1}

\begin{tabular}{|l|l|l|}
\hline lemma & $\mathrm{VAW}^{7}$ & $\mathrm{VAW}^{\mathbf{8}}$ \\
\hline Boer & $\begin{array}{l}\text { Suid-Afrikaner van Hollandse afkoms; } \\
\text { die } \sim \text { in hom is dood, hy is verengels }\end{array}$ & $\begin{array}{l}\text { Afrikaner van Nederlandse, Franse en Duitse } \\
\text { herkoms; die }- \text { in hom is dood, hy is verengels }\end{array}$ \\
\hline
\end{tabular}

'n Mens wonder onwillekeurig of die kategoriese skrapping van alle leksikale items wat as eensydig rassisties aangevoel is, nie dalk gemotiveer is deur die agste uitgawe van $A W S$, waarin meer as veertig rassistiese woorde geskrap is nie. Die skrappings in die $A W S$ is natuurlik volkome verstaanbaar aangesien dié bron 'n gespesialiseerde normatiewe woordeboek is wat nie voorsiening maak vir genuanseerde kommentaar nie, en wat onverantwoordelik sou optree indien 'sensitiewe' leksikale items ongekommentarieerd opgeneem sou word. (Vergelyk in hierdie verband Hauptfleisch 1993:119-120.) Dieselfde oorwegings kan egter nie vir 'n deskriptiewe woordeboek soos $V A W$ geld nie en 'n kernvraag, wat aansluit by die gemelde polemiek tussen Esterhuyse en Webb (kyk 5.1 hierbo), is of dit wel die taak van 'n sinchronies-deskriptiewe woordeboek is om politiesideologiese sensuur op so 'n radikale wyse toe te pas.

As argument ten gunste van volledige skrapping sou wel aangevoer kon word dat rassistiese leksikale items eensydig geskep is deur 'n gedeelte van die Afrikaanssprekende bevolking en om dié rede geen legitimiteit het nie. Die argument sou verder gevoer kon word deur te voorspel dat hierdie leksikale items spoedig in die postapartheid-Suid-Afrika uit die leksikons van taalgebruikers sal verdwyn, en daarmee saam ook die stereotipiese raskategorieë wat so lank daardeur bevestig is. Die belangrikste argument téén volledige skrapping sou wees dat 'n standaardwoordeboek primêr 'n deskriptiewe opdrag het en dat gebruiksfrekwensie inderdaad nog wel die opname van bepaalde rassismes regverdig. Alleen die tyd sal leer of die outeurs van $V A W^{\beta}$ deur hulle skrappingsbeleid verantwoordelik opgetree het, en taalgebruikstendense in die nabye toekoms korrek voorspel het.

Wat HAT betref, lyk die situasie ietwat anders. Sowel uit die "Voorwoord" (toeligtende aantekeninge) van $H A T^{3}$ as in 'n bespreking van die woordeboek in Beeld van Woensdag 18 Mei 1994, is dit duidelik dat die samestellers opreg daarna gestreef het om die ideologiese normverplasings van die afgelope dekade 
te weerspieël, maar sonder om 'volstruispolitiek' te bedryf wat tot 'n 'verwronge beeld' sou kon lei. In die "Voorwoord" word eksplisiet gemeld dat kwetsende terme op die gebied van veral ras, maar ook geslag, godsdiens, politiek en spotname tot die minimum beperk is.

Onder die rassismes wat weggelaat is, ressorteer veral eensydig en eenduidig kwetsende komplekse lemmas soos kaffermeid en kafferboetie asook komplekse lemmas waarby die rasbenaming 'n minderwaardige gehalte aandui ten opsigte van die saak wat benoem word, byvoorbeeld kafferblits ("goedkoop brandewyn"), kafferhond ("onaansienlike hond of brak van gemengde ras") en kafferwerk ("werk wat ... benede die waardigheid van 'n witmens geag word"). Gebruiklike benaminge vir plante en diere wat 'n rasbenaming as eerste komponent bevat - byvoorbeeld kafferboom, kaffer-wag-'n-bietjie, kafferslangwortel en kafferwaatlemoen - is moontlik behou omdat hulle nie eksplisiet raskwetsend is nie, of omdat daar gemeen is dat skrapping 'n leksikale leemte sou laat.

\subsubsection{Mikrostrukturele verstellings}

Dit is duidelik dat die outeurs van $V A W^{8}$ daarmee erns gemaak het om alle definiense wat rassistiese elemente bevat, te herskryf. Onder $\mathrm{K}$ in $V A W^{8}$ vind 'n mens verstelde definisies by onder andere die lemmas kampong, kikuyu, kombersdraer, Korana, Kreool, Kris, kroeskop en kussingblok. Feitlik deurgaans is kwetsende verwysings na ras en bloedvermenging volledig geskrap. Die woord/ woorddeel Bantoe is deurgaans in definiense geskrap of vervang, en Hottentotte is vervang met Koikoi. Hoewel $V A W^{8}$ baie moeite gedoen het om rassisme te verwyder, het daar egter tog definiense deurgeglip wat steeds as diskriminerend ervaar kan word, soos in die geval van kombersdraer: "iemand wat nog nie onder die invloed van die blanke beskawing is nie".

Hoewel $H A T^{3}$ bepaalde rassismes as lemmas behou het, is ernstig gepoog om die kwetsende aard daarvan aan te toon met behulp van etikette of kommentaar/ gebruiksadvies aan die einde van die definiens, soos in die geval van die lemmas Kaffer, kaffer-, Kleurling en Hotnot. Die kommentaar of gebruiksnota, wat in $H A T^{3}$ dikwels aan die einde van die definiens (na 'n aandagstreep) aangebied word, stel dit meestal eksplisiet dat die betrokke leksikale item as kwetsend ervaar word en doen dan 'n beroep op die gebruiker om die gebruik daarvan liefs te vermy. In Tabel 2 hieronder word die gebruiksadvies deur onderstreping gemerk.

Om die opname van ' $n$ aantal plant- en diername met die pejoratiewe rasbenaming kaffer- as eerste lid te motiveer, is kaffer- as 'n poststreeplemma opgeneem en soos volg gedefinieer: "Nog veel voorkomend as eerste lid van benaminge vir plante, diere en instrumente en dan moeilik te vermy en stellig meer neutraal aangevoel." Ten spyte van die samestellers se goeie bedoelings is die definiens 
lomp geformuleer en ontbreek 'n eksplisiete kruisverwysing na die leksikale lemma Kaffer, waarmee die streeplemma vergelyk word deur middel van die klous "meer (outeur se kursivering) neutraal aangevoel" (vergelyk Tabel 2 hieronder).

Dit is verblydend dat die samestellers van $H A T^{3}$ in die definiens van Boer met behulp van 'n gebruiksnota aandui dat dié leksikale item sowel 'n melioratiewe as 'n pejoratiewe gebruikstoepassing het. Ongelukkig word hierdie gebruiksvariasie nie geillustreer aan die hand van voorbeelde nie, en weerspieël die onverklaarde komposita $\sim$ dogter, $\sim$ nooi, $\sim$ seun en $\sim$ volk slegs die melioratiewe gebruik. Verder verdien 'n bepaalde sekondêre betekenisonderskeiding wat uit die pejoratiewe gebruikstoepassing ontstaan het, naamlik "wit geregsdienaar", 'n aparte poliseemnommer en 'n aparte definisie. Polisemiese hantering sou gerugsteun kon word deur die feit dat 'n mens by Boer duidelik met twee afsonderlike klasse van objekte te doen het, te wete 'rasgroep' en 'geregsdienaar'.

Gebruiksadvies en pragmatiese kommentaar is egter nie die enigste middele wat in $H A T^{\mathfrak{b}}$ gebruik is om rassisme te bekamp nie. Kwetsende (en soms selfs ook niekwetsende) gebruiksvoorbeelde, sinonieme, vaste uitdrukkings en onverklaarde komposita is by inherent rassistiese lemmas feitlik sonder uitsondering geskrap. Die lemmas Kleurling en Kaffer in $H A T^{3}$ (vergelyk Tabel 2) illustreer hierdie beleid en strategie. (Let wel, die deurstrepings in die $H A T^{2}$-artikels dui op inligting wat in $H A T^{d}$ geskrap is en die onderstrepings dui op toevoegings in $H A T^{d}$.)

\section{Tabel 2}

\begin{tabular}{|c|c|c|}
\hline lemma & $\mathrm{HAT}^{2}$ & $\mathrm{HAT}^{3}$ \\
\hline Boer & $\begin{array}{l}\text { Lid van die Afrikanervolk; Afrikaner: Ek } \\
\text { is mos Boer se kind. Boer(c): .dogter, } \\
\text {.. nooi, ..seun, ..volk }\end{array}$ & 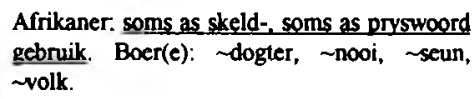 \\
\hline Klcurlinge & 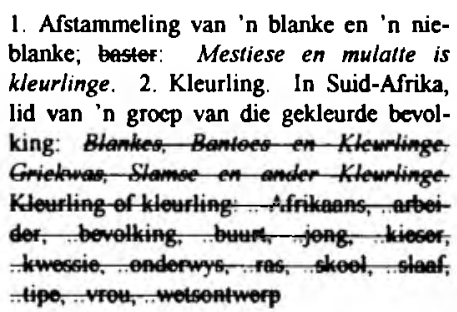 & $\begin{array}{l}\text { 1. Afstammeling van 'n blanke en 'n nie- } \\
\text { blanke: Mestiese en mulatte is kleurlinge. } 2 . \\
\text { Kleurling. In Suid-Afrika, lid van 'n groep } \\
\text { van die gekleurde bevolking - deur die meeste } \\
\text { persone toenoor of van wie dit gebruik word. } \\
\text { as necrhalend en diskriminerend aangevoel. } \\
\text { en dus liefs te vermy. }\end{array}$ \\
\hline
\end{tabular}




\begin{tabular}{|c|c|c|}
\hline Kaffer' & 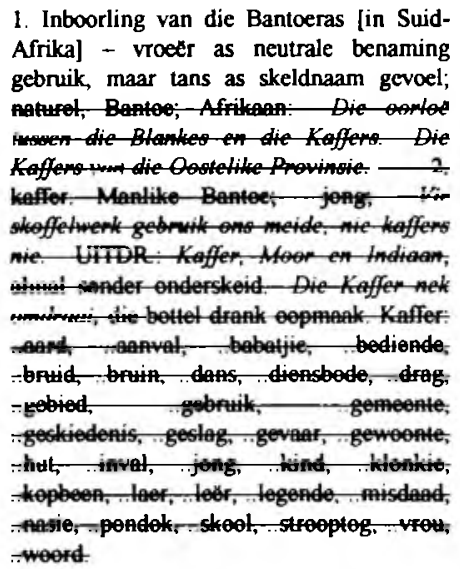 & $\begin{array}{l}\text { Benaming vir 'n lid van 'n swart ras in Suid- } \\
\text { Afrika, maar ook vir 'n lid van ander groexe } \\
\text { soos Negers - vroetr veelal 'n neutrale } \\
\text { benaming, maar tans sterk neerhalend of as } \\
\text { skeldnaam ervaar, en dus te vermv. }\end{array}$ \\
\hline kaffer- $^{2}$ & 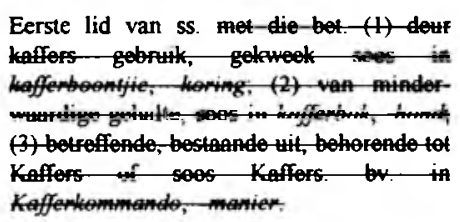 & $\begin{array}{l}\text { Nog veel voorkomend as eerste lid van } \\
\text { benaminge vir plante, diere en instrumente exn } \\
\text { dan mocilik te vermy en stellig meer neutraal } \\
\text { aangevoel. }\end{array}$ \\
\hline Hotnot & Wisselvorm van Hottentot. & $\begin{array}{l}\text { Wisselvorm van Hottentot - tans as vorm en } \\
\text { benaming as beledigend ervaar deur persone } \\
\text { van en tcenoor wie dit gebruik word, en dus te } \\
\text { vermy. }\end{array}$ \\
\hline
\end{tabular}

Soos $V A W^{8}$ moet ook $H A T^{b}$ geprys word vir die skrapping van onnodige rasverwysings en voorbeelde waarin rasgroepe negatief gestereotipeer word, veral waar dit nie noodsaaklik vir die betekenisverklaring van die betrokke lemma is nie.

\subsection{Polities-ideologiese diskriminasie}

Leksikale items wat tot die politieke register behoort, word deur sommige taalkundiges as meerduidig, vaag en vloeibaar gekarakteriseer. Gallie (1964) beskryf byvoorbeeld die terme van die politieke diskoers as "essentially contested concepts" en Hughes (1988) noem hulle "zombie words".

Die Duitse metaleksikograwe Hermanns (1982) en Strauss $(1982 ; 1986)$ toon egter aan dat daar binne die polities-ideologiese register, waartoe leksikale items soos demokrasie, kommunisme, kapitalisme, liberaal en konserwatief behoort, 
tog 'n aansienlike mate van semanties-pragmatiese sistematiek aanwesig is. In die verband onderskei Strauss $(1986: 68-78 ; 159)$ tussen polisemiese onderskeidings en variante gebruike.

Talle leksikale items wat in die politieke domein gebruik word, is polisemies omdat hulle variant in verskillende subsisteme van die taal gebruik word, byvoorbeeld enersyds in die omgangstaal en andersyds in die vaktaal van die politieke wetenskappe. Leksikale items binne die politieke domein word egter ook polisemies gebruik deurdat hulle op verskillende semantiese dimensies (genuskategorieë) van toepassing gemaak kan word. Soos uit Tabel 3 en 4 afgelees kan word, weerspieël sowel $H A T^{3}$ as $V A W^{\delta}$ leksikale polisemie by die lemma kommunisme/ Kommunisme. $V A W^{\beta}$ onderskei by Kommunisme op polisemiese vlak tussen "leer", "stelsel" en "partystelsel". $H A T^{3}$ gee weer op voortreflike wyse gestalte aan die abstrakte en konkrete toepassings van die lemma demokrasie, wat met behulp van die superordinate "regeringsvorm" en "staat" onderskei word. (Vergelyk Tabel 4.)

Die nievakkundige betekenisonderskeidings van leksikale items wat tot die politieke domein behoort, vertoon dikwels nog verdere variasie. Hulle word naamlik variant deur verskillende ideologiese sprekersgroepe in verskillende ideologiespesifieke toepassings gebruik. Gebruiksvariasie (met ander woorde variasie binne ' $n$ enkele polisemiese onderskeiding) word deur die Duitse metaleksikograwe Strauss (1982 en 1986) en Hermanns (1982) met die term ideologiese polisemie benoem. 'n Leksikale item kan in 'n bepaalde betekenisonderskeiding ideologies-polisemies optree indien dit een of meer van die volgende tipes variasie vertoon:

- variante periferale deskriptiewe waardes;

- variante evaluasies (melioratief of pejoratief);

- variante groepfokus (eiegroepverwysing of vreemdegroepverwysing).

Hierdie tipes variasie kan geillustreer word aan die hand van semantiese skemas (gebaseer op die teorie van kognitiewe modelle) ${ }^{1}$ vir afsonderlike polisemiese onderskeidings van polities-ideologiese leksikale items. Vergelyk onder andere

1 Volgens Gcorge Lakoff (1987:68 e.v.) is kognitiewe modelle ervaringsgebascerde mentale strukture wat die menslike denke, handelinge én taalgebruik struktureer en motiveer. Semantiese skemas is grafiese voorstellings van die betekenisse van leksikale items, waarin die reelmatige kognitief-semantiese aspekte van leksikale items behorende tot 'n bepaalde pragmaticse domein (byvoorbeeld politicke ideologie) verreken word deur dic spesifisering van bepaalde 'gleuwe', en die idiosinkratiese scmantiese aspekte verreken word deur 'vullers' 
die volgende skemas vir die abstrakte betekenisonderskeidings van die leksikale items demokrasie en kapitalisme:

\section{Skema 1: demokrasie}

\begin{tabular}{|l|l|l|}
\hline & Gebruikersgroep A & Gebruikersgroep B \\
\hline $\begin{array}{l}\text { Deskriptiewe } \\
\text { betekenis } \\
\text { (sentraal) }\end{array}$ & $\begin{array}{l}\text { Regeringsvorm waarin die volk deel het } \\
\text { aan die magsuitoefening van die staat }\end{array}$ & $\begin{array}{l}\text { Regeringsvorm waarin die volk decl het } \\
\text { aan die magsuitoefening van die staat }\end{array}$ \\
\hdashline $\begin{array}{l}\text { Deskriptiewe } \\
\text { betekenis } \\
\text { (periferaal) }\end{array}$ & $\begin{array}{l}\text { deur die verkiesing van parlementêre } \\
\text { verteenwoordigers }\end{array}$ & $\begin{array}{l}\text { deur regstreekse inspraak en deelname } \\
\text { van dic werkers }\end{array}$ \\
\hline Evaluering & Melioratief & Melioratief \\
\hline Groepfokus & Eiegroepverwysing & Eiegroepverwysing \\
\hline
\end{tabular}

\section{Skema 2: kapitalisme}

\begin{tabular}{|l|l|l|}
\hline & Gebruikersgroep A & Gebruikersgroep B \\
\hline $\begin{array}{l}\text { Deskriptiewe } \\
\text { betekenis } \\
\text { (sentraal) }\end{array}$ & $\begin{array}{l}\text { Maatskaplik-ekonomiese stelsel wat op 'n } \\
\text { vryemarkstelsel gegrond is en deur indivi- } \\
\text { due eerder as deur die Staat beheer word, }\end{array}$ & $\begin{array}{l}\text { Maatskaplik-ekonomiese stelsel wat op 'n } \\
\text { vryemarkstelsel gegrond is en deur indivi- } \\
\text { due eerder as deur die Staat beheer word, }\end{array}$ \\
\hline $\begin{array}{l}\text { Deskriptiewe } \\
\text { betekenis } \\
\text { (periferaal) }\end{array}$ & $\begin{array}{l}\text { veral gekenmerk deur privaatbesit en die } \\
\text { vryheid van die individu, met gevolglike } \\
\text { vinnige toename in kapitaalrykdom en } \\
\text { materiẻle welvaart }\end{array}$ & $\begin{array}{l}\text { veral gekenmerk deur die uitbuiting van } \\
\text { loonarbeiders en die privaat toexiening } \\
\text { van produksiemiddele deur lede van die } \\
\text { besittersklas }\end{array}$ \\
\hline Evaluering & Melioratief & Pejoratief \\
\hline Groepfokus & Eiegroepverwysing & Vreemdegroepverwysing \\
\hline
\end{tabular}

Indien hierdie skemas vergelyk word met die artikels van die ooreenstemmende lemmas in Afrikaanse handwoordeboeke (vergelyk Tabel 3 en 4 hieronder), blyk dit dat hierdie woordeboeke die betekenis- en gebruiksvariasie binne die politiesideologiese leksikon baie fragmentaries weerspieël. Dit blyk ook verder dat die negentigers nie voldoende aandag skenk aan semanties-ideologiese verskuiwings wat gedurende die afgelope dekade binne die polities-ideologiese leksikon van Afrikaans plaasgevind het nie. 


\section{Tabel 3}

\begin{tabular}{|c|c|c|}
\hline Iemma & $\mathbf{V A W} \mathbf{W}^{7}$ & $\mathbf{V A W} \mathbf{W}^{8}$ \\
\hline demokrasie & $\begin{array}{l}\text { regeringsvorm waarby die hoogste } \\
\text { gesag by die volk berus, volksregering. }\end{array}$ & $\begin{array}{l}\text { Regeringsvorm waarby die hoogste gesag } \\
\text { by die volk berus, volksregering. }\end{array}$ \\
\hline kommunisme & $\begin{array}{l}\text { lewensrigting, denkwyse wat alle pri- } \\
\text { vaat besit wil ophef, alles gemeenskap- } \\
\text { like eiendom wil maak en alle sosiale } \\
\text { skeidinge wil verwyder, 'n uiterste } \\
\text { vorm van sosialisme; ..nisties. }\end{array}$ & $\begin{array}{l}\text { Lewensrigting, denkwyse wat alle privaat } \\
\text { besit wil ophef, alles gemeenskaplike } \\
\text { eiendom wil maak en alle sosiale } \\
\text { skeidinge wil verwyder, 'n uiterste vorm } \\
\text { van sosialisme; ..nisties. }\end{array}$ \\
\hline kommunisme & $\begin{array}{l}\text { leer waarvolgens g'n privaat eiendom } \\
\text { mag bestaan nie, alleen gemeenskaplike } \\
\text { besit; stelsel van gemeenskaplike besit } \\
\text { en arbeid en afskaffing van privaat } \\
\text { besit; Kommunistiese Partystelsel. }\end{array}$ & $\begin{array}{l}\text { 1. Leer waarvolgens g'n privaat eiendom } \\
\text { mag bestaan nie, alleen gemeenskaplike } \\
\text { besit. } 2 \text {. Stelsel van gemeenskaplike besit } \\
\text { en arbeid en afskaffing van privaat besit. } \\
\text { 3. Kommunistiese Partystelsel }\end{array}$ \\
\hline kapitalisme & $\begin{array}{l}\text { toestand van kapitaal te besit; } \\
\text { ekonomiese stelsel wat kapitaliste } \\
\text { voortbring en waar die winsmotief } \\
\text { deurslaggewend is; stelsel van lewens- } \\
\text { beskouing en -praktyk wat maatskappy, } \\
\text { staat, volkere en die wêreld met alle } \\
\text { werk- en produksiebronne wil beheer en } \\
\text { bestuur deur die mag van en vir die } \\
\text { uitbreiding van geldbesit en persoonlike } \\
\text { rykdom. }\end{array}$ & $\begin{array}{l}\text { 1. Toestand van kapitaal te besit. } \\
\text { 2. Ekonomiese stelsel wat kapitaliste } \\
\text { voortbring en waar die winsmotief } \\
\text { deurslaggewend is. } 3 \text {. Stelsel van le- } \\
\text { wensbeskouing en -praktyk wat } \\
\text { maatskappy, staat, volkere en die wèreld } \\
\text { met alle werk- en produksiebronne wil } \\
\text { behoer en bestuur deur die mag van en } \\
\text { vir die uitbreiding van geldbesit en } \\
\text { persoonlike rykdom. }\end{array}$ \\
\hline $\begin{array}{l}\text { liberaal } \\
\text { (b.nw. en bw.) }\end{array}$ & $\begin{array}{l}\text { vrygewend, milddadig, met 'n ruim } \\
\text { opvatting. onbekrompe; onbevoor- } \\
\text { cordeeld; nie streng van opvatting } \\
\text { insake godsdiens nie; vrysinnig, verlig. }\end{array}$ & $\begin{array}{l}\text { 1. Vrygewend, milddadig. 2. Met 'n ruim } \\
\text { opvatting, onbekrompe. 3. Onbevooroor- } \\
\text { decld. 4. Nie streng van opvatting insake } \\
\text { godsdiens nie. 5. Vrysinnig, verlig. }\end{array}$ \\
\hline $\begin{array}{l}\text { konserwatief } \\
\text { (b.nw.) }\end{array}$ & $\begin{array}{l}\text { behoudend; wat aan die ou idees en } \\
\text { gebruike vashou. }\end{array}$ & $\begin{array}{l}\text { Behoudend; wat aan die ou idees en } \\
\text { gebruike vashou. }\end{array}$ \\
\hline
\end{tabular}

\section{Tabel 4}

\begin{tabular}{|l|l|l|}
\hline Iemma & HAT & HAT $^{3}$ \\
\hline demokrasie & $\begin{array}{l}\text { Regeringsvorm deur verteenwoordigers } \\
\text { van die hele volk gekies; volksregering. } \\
\text { IG. demos volk + kratos krag]. } \\
\text { demokraties. }\end{array}$ & $\begin{array}{l}\text { 1. Regeringsvorm deur vertecnwoordigers } \\
\text { uit die hele volk gekies, gekenmerk deur } \\
\text { vryheid van spraak, van die individu, van } \\
\text { die reg; volksregering. 2. Staat met so 'n } \\
\text { regeringsvorm. [G. demos volk + kratos } \\
\text { kragl. }\end{array}$ \\
\hline
\end{tabular}




\begin{tabular}{|c|c|c|}
\hline kommunisme & $\begin{array}{l}\text { 1. Sosiale en politieke leer, gebaseer op } \\
\text { die beginsels van Karl Marx ( }(1883) \text {, } \\
\text { wat die geskiedenis vertolk met as } \\
\text { uiteindelike resultaat 'n orwinning deur } \\
\text { die proletariaat en die vestiging van 'n } \\
\text { stelsel van gemeenskaplike besit van } \\
\text { produksie- en verbruiksmiddele. } 2 \text {. To- } \\
\text { talitariese regeringstelsel waarin die } \\
\text { staat eienaar is van die vernaamste } \\
\text { nywerhede en deur middel van een party } \\
\text { die ekonomiese, maatskaplike en } \\
\text { kulturele lewe van die volk beheer. }\end{array}$ & $\begin{array}{l}\text { 1. Sosiale en politieke leer, gebaseer op } \\
\text { die beginsels van Karl Marx ( } \pm 1883) \text {, wat } \\
\text { die geskiedenis vertolk met as uiteindelike } \\
\text { resultaat 'n orwinning deur die } \\
\text { proletariaat en die vestiging van 'n stelsel } \\
\text { van gemeenskaplike besit van produksie- } \\
\text { en verbruiksmiddele. } 2 \text {. Totalitariese } \\
\text { regeringstelsel waarin die staat eienaar is } \\
\text { van die vernaamste nywerhede en deur } \\
\text { middel van een party die ekonomiese, } \\
\text { maatskaplike en kulturele lewe van die } \\
\text { volk beheer. }\end{array}$ \\
\hline kapitalisme & $\begin{array}{l}\text { 1. Ekonomiese stelsel gegrond op private } \\
\text { besit en mededinging, met 'n minimum } \\
\text { staatsbeheer: Die sosialiste voer 'n } \\
\text { verbete stryd teen die kapifalisme. } \\
2 \text {. Konsentrasie van kanitaal met die } \\
\text { mag en invloed wat dit meebring, in die } \\
\text { hande van 'n klein aantal: Die gevaar } \\
\text { van die kanitalisme. }\end{array}$ & $\begin{array}{l}\text { Ekonomiese stelsel gegrond op private } \\
\text { besit, belegging en mededinging, met 'n } \\
\text { minimum staatsbeheer, waardeur geld en } \\
\text { besittings dus in private hande is: } \\
\text { Kapitalisme is die grondslag van die } \\
\text { Westerse ekonomie. Die sosialiste voer 'n } \\
\text { verbete stryd teen die kapitalisme. }\end{array}$ \\
\hline $\begin{array}{l}\text { liberagl } \\
\text { (b.nw. en bw.) }\end{array}$ & $\begin{array}{l}\text { 1. Vrysinnig, nim denkend; nie- } \\
\text { ortodoks; Liberole beskouinge. } 2 . \\
\text { Onbekrompe, onbevooroordeeld; bereid } \\
\text { om hervorminge in te voer, o.a. op } \\
\text { politieke gebied; ook veral in S.A. } \\
\text { minder of meer links gesind. }\end{array}$ & $\begin{array}{l}\text { 1. Vrysinnig, ruim denkend; nie-ortodoks; } \\
\text { Liberale beskouinge. } 2 \text {. Onbekrompe, } \\
\text { onbevooroordeeld; bereid om hervor- } \\
\text { minge in te voer, o.a. op politieke gebied. }\end{array}$ \\
\hline $\begin{array}{l}\text { konserwatief } \\
\text { (b.nw.) }\end{array}$ & $\begin{array}{l}\text { Aan die bestaande toestand geheg, } \\
\text { afkerig van ingrypende hervorming; } \\
\text { behoudend: 'n Konserwatiewe politikus. } \\
\text { 'n Konserwatiewe koerant, tydskrif. } \\
\text { Dominee is baie konserwatief, hou nie } \\
\text { van nuwighede nie. }\end{array}$ & $\begin{array}{l}\text { Aan die bestaande toestand geheg, afkerig } \\
\text { van ingrypende hervorming; behoudend: } \\
\text { 'n Konserwatiewe politikus. in } \\
\text { Konserwatiewe koerant, tydskrif. Dominee } \\
\text { is baie konserwatief, hou nie van } \\
\text { nuwighede nie. }\end{array}$ \\
\hline
\end{tabular}

\section{Onsuksesvolle definiëringsmetodes}

Die negentigers onder bespreking is veral skuldig aan die gebruik van twee onsuksesvolle definiëringsmetodes:

\section{- Redusering tot die gemene deler}

In hoofsaak hou hierdie strategie in dat gepoog word om alle ideologiese gebruikersperspektiewe onder een ongedifferensieerde noemer te akkommodeer. Benewens die feit dat hierdie strategie dikwels tot 'n semanties ondergespesifiseerde definiens lei, is Good (1987:7) van mening dat "Middle of the roaddefinitions raise questions about whose road it is and who decides where the middle is" - met ander woorde neutraliteit is 'n ideaal wat selde bereik word. 
$V A W$ gee in sowel die sewende as die agste uitgawe geen aanduiding van die variante polities-ideologiese gebruike van die lemmas demokrasie en konserwatief nie (vergelyk Tabel 3 hierbo). Hierdie lemmas word in neutrale of selfs ietwat positiewe terme gedefinieer. Konserwatief. het egter binne Afrikaans (in sy wydste omvang) duidelik uiteenlopende periferale deskriptiewe waardes, evaluasies én groepverwysings. Bepaalde groepe evalueer die leksikale item konserwatief as pejoratief, gebruik dit slegs vreemdegroepverwysend en heg die konnotasies "verkramp/reaksionêr" daaraan. Ander groepe evalueer dit weer melioratief, gebruik dit slegs eiegroepverwysend en heg die konnotasie "met behoud van beproefde waardes" daaraan. Slegs die deskriptiewe kernbetekenis word egter deur $V A W$ weerspieèl. Naas die feit dat $H A T^{3}$ se definiens óok te algemeen is (vergelyk Tabel 4), is verder gefouteer deur die volgende negatief stereotiperende gebruiksvoorbeeld te behou: Dominee is baie konserwatief.

\section{- Ideologies eensydige definiëring}

'n Ander ongewensde strategie is om die lemma te definieer vanuit 'n enkele, nieverteenwoordigende polities-ideologiese perspektief - 'n perspektief wat die wit besittersklas as deiktiese sentrum het. Hierdie strategie is selfs meer ongewens as die vorige omdat dit neerkom op diskriminasie. Dit is daarom te betreur dat $H A T^{\mathfrak{b}}$ die pejoratiewe gebruik van die leksikale item kapitalisme, wat in die tweede uitgawe wel as 'n afsonderlike betekenisonderskeiding aangebied is, geskrap het (vergelyk Tabel 4). Hoewel twee volkome afsonderlike polisemiese onderskeidings nie regverdigbaar is nie, sou die gebruiksvariasie wel binne subbetekenisonderskeidings geakkommodeer kon word.

Dit is wel verblydend dat $H A T^{3}$ betekenisonderskeiding 2 van liberaal gewysig het om by die veranderde sosio-politieke beskouinge van die postapartheidsera aan te sluit. Liberaal is wel vroeerr gebruik om pejoratief te verwys na politieke beskouinge wat as links-van-die-regering, of selfs revolusionêr geag is. Saam met die politieke hergroeperings van die tagtigerjare en die 'liberalisering' van die Nasionalepartyregering het hierdie betekenisaspek egter verdwyn. Vandag word liberaal deur die middestroompartye slegs melioratief en eiegroepverwysend gebruik om te verwys na persone en instansies wat bereid is om gewensde verandering/hervorming te aanvaar. Ongelukkig bly die definiens eensydig deurdat die betekenisaspek wat deur ANC-, PAC- en SAKP-gesindes aan dié woord geheg word, nie verreken is nie. Hierdie groepe gebruik liberaal vreemdegroepverwysend met betrekking tot groepe/persone wat as onmiddellik regs van die ANCgedomineerde regering beskou word (byvoorbeeld aanhangers van die NP en DP) - groepe/persone 'wat voorgee dat hulle onbevooroordeeld en nierassisties is'. 


\section{Slotsom}

Afrikaanse handwoordeboeke van die negentigerjare getuig oor die algemeen van groter gebruiksvriendelikheid as hulle voorgangers. Eerstens is meer aandag geskenk aan gebruikerstoeligting by wyse van praktiese riglyne en verduidelikings in die nie-alfabetiese gedeelte. Teenoor $H A T$ wat eksplisiete beleidstellings oor ideologies-kwetsende lemmas in sy "Voorwoord" maak, vind 'n mens in VAW se "Gids vir die gebruiker" egter geen sodanige toeligting nie. Tweedens is bepaalde ideologiese aangeleenthede soos rassisme (en seksisme) met groter omsigtigheid gehanteer - of 'n mens nou met die betrokke woordeboek se hanteringswyse saamstem of nie.

Een van die negentigers se grootste swakpunte is egter dat polities-ideologiese aangeleenthede nog nie bevredigend gehanteer is nie. Die volgende moontlike redes kan aangevoer word:

- Weens die internasionale karakter van polities-ideologiese leksikale items is die betekenisse en gebruikswaardes wat hulle in Afrikaans het, moontlik gelykgestel aan dié wat hulle in sustertale soos Engels, Nederlands en Duits het. Woordeboeke in dié tale kon moontlik as rolmodelle gedien het met betrekking tot die hantering van polities-ideologiese leksikale items. Vergelyk in hierdie verband die primêre betekenisonderskeiding van die lemma liberaal in $V A W$ (Tabel 3 hierbo). Hierdie betekenisonderskeiding kom glad nie in hedendaagse Afrikaans voor nie, maar wel in Engels.

- Tweedens is dit moontlik dat die sosiopolitieke veranderings in 'n postapartheid-Suid-Afrika sterker eise gestel het met betrekking tot aanpassings binne ideologiese terreine soos rassisme en seksisme - veral omdat leksikale items binne hierdie terreine as eensydig kwetsend aangevoel is en omdat drukgroepe sterker teen die aanwesigheid daarvan in normatiewe taalbronne beswaar gemaak het as teen die eendimensionele hantering van polities-ideologiese leksikale items.

Een van die uitdagings aan die Afrikaanse woordeboekgeslag van 2000 sou wees om 'die oor op die grond te hou' en erkenning te gee aan 'alternatiewe' politiesideologiese normsisteme wat binne die Afrikaanssprekende gemeenskap bestaan. Verder sal toekomstige wisselinge in die verhoudings tussen opposisionele ideologiese groepe fyn waarnemings noodsaak rondom die semantiek en pragmatiek van polities-ideologiese leksikale items. 


\section{Bronnelys}

Bartsch, R. 1981. Kommunikatienormen en lexikale verandering, Tijdschrift voor Tekst-en Taalwetenschap, 2:83-101.

Bartsch, R. 1982. The Concepts "Rule" and "Norm" in Linguistics, Lingua, 58:51-81.

Carstens, W.A.M. 1994. Norme vir Afrikaans. Pretoria : J.L. Van Schaik.

Combrink, J.G.H. 1984. Wat is 'n Anglisisme? In: Botha, T.J.R. (red.). Inleiding tot die Afrikaanse Taalkunde. Pretoria : Academica. pp. 83-106.

Combrink, Johan \& Spies, Johan. 1986. Sakboek van regte Afrikaans (SARA). Kaapstad : Tafelberg.

Esterhuyse, J. 1987. Die politieke taal van 'n Afrikaanse woordeboek. In: Du Plessis H. \& Du Plessis T. (reds.). Afrikaans en taalpolitiek. Johannesburg : Taurus. pp. 123-130.

Gallie, W.B. 1964. Philosophy and the Historical Understanding. London : Chatto \& Windus.

Good, C.H. 1987. Lexicography and Linguistic Theory with Special Reference to German. Studia Neophilologica, 59:65-77.

Gouws, R.H. 1989. Leksikografie. Pretoria : Academica.

Gouws, R.H. 1993. Normatiewe leiding in woordeboeke: 'n nuwe benadering. In: Harteveld, P. (red.). LEXIKOS 3. Stellenbosch : Buro van die WAT. pp. 49-66.

Hauptfleisch, D.C. 1993. Racist Language in Society and in Dictionaries. A Pragmatic Perspective. In: Harteveld, P. (red ). LEXIKOS 3. Stellenbosch : Buro van die WAT. pp. 83-139

Hermanns, F. 1982. Brisante Worter: Zur lexicographishen Behandlung parteisprachlicher Worter und Wendungen in Wöterbüchern der deutschen Gegenwartssprache. In: Wiegand, H.E. (red). Studien zur Neuhochdeutschen Lexicographie II. Germanistische Linguistik 3-6/80. Hildesheim : Georg Olms. pp. 87-108.

Hughes, G. 1988. Words in Time. Oxford : Basil Blackwell.

Johnson, M. 1987. The Body in the Mind. Chicago/London : University of Chicago Press.

Kritzinger, M.S.B. \& Labuschagne, F.J. 1980. Verklarende Afrikaanse Woordeboek Pretoria : J.L. van Schaik.

Labuschagne, F.J. \& Eksteen, L.C. 1992. Verklarende Afrikaanse Woordeboek ${ }^{8}$. Pretoria J.L. van Schaik.

Lakoff, G. 1987. Women, Fire and Dangerous Things. Chicago/London : University of Chicago Press.

Odendal, F.F., Schoonees, P.C., Swanepoel, C.J., Du Toit, S.J. \& Booysen, C.M. 1979. Verklarende Handwoordeboek van die Afrikaanse Taal'. Johannesburg : Perskor.

Odendal, F.F., Schoonees, P.C., Swanepoel, C.J., Du Toit, S.J. \& Booysen, C.M. 1994. Verklarende Handwoordeboek van die Afrikaanse Taal'. Midrand : Perskor.

Strauss, G. 1982. Aspekte des Sprachaussnitts 'Politik' im einsprachigen Wörterbuch: Politisch-Ideologische Ismen - Lexicographisch betrachtet. In: Mentrup, W. (red.). Konzepte zur Lexicographie: Studien zur Bedeutungserklairung in einsprachigen Wörterbücher. Reihe Germanistische Linguistik 38. Tübingen : Max Niemeyer. pp. 3464.

Strauss, G. 1986. Der politische Wortschatz. Zur kommunikation und Textsortenspezifik. Tubingen : Gunther Narr.

Taalkommisie. 1991. Afrikaanse Woordelys en Spelreëls . Kaapstad : Tafelberg.

Van der Merwe, H.J.J.M. \& Ponelis, F.A. 1991. Die korrekte woord . Pretoria : J.L. van Schaik. 
Van Rensburg, Christo. 1992. Die demokratisering van Afrikaans. In: Webb, V.N. (red.). Afrikaans na apartheid. Pretoria : Van Schaik. pp. 183-197.

Van Rensburg, Christo. 1994. Die ontstaan van Afrikaans in 'n intertaalkonteks. In: Coetzee, A. \& Olivier, G. (reds.). Nuwe perspektiewe op die geskiedenis van Afrikaans. Johannesburg : Southern. pp. 167-180.

Webb, V.N. 1989. Enkele gepolitiseerde woorde in Afrikaans, HAT en die Sosiolinguistiek. In: Botha, T.J.R. (red). Leksikografie en leksikologie. Pretoria : Serva. pp. 129-142.

Zgusta, L. 1971. Manual of Lexicography. The Hague : Mouton. 